\title{
THE DYNAMICS OF AFRICA IN WORLD AFFAIRS: FROM AFRO-PESSIMISM TO AFRO-OPTIMISM?
}

\author{
Sharkdam Wapmuk ${ }^{1}$ \\ Oluwatooni Akinkwotu ${ }^{2}$
}

\section{Introduction}

The article argues that Africa has never existed apart from world politics, but has been inevitably entangled in the dynamics and flow of events and changing configurations of global power. Historical records have clearly confirmed that there have been contacts, interactions and a flow of both ideas and goods between Africa, Europe, Asia and Americas. Whether the continent's historical contacts and interactions with the rest of the world have been a 'curse or blessing' has been a subject of serious debate (Adekaye 20I0). African affairs have contributed in shaping the world and Africa in turn, has been, and is still being shaped by international processes and structures. The study of Africa in world affairs has no doubt attracted scholarly interest. However, most studies on the continent, especially in the past two decades tend to focused on the negative narrative - crisis, war, poverty, natural disasters, corruption, diseases and famine, criminality, environmental degradation, mismanagement of natural resources and crisis of governance (Zartman I995). Some even completely wrote-off the continent as a 'hopeless case', 'dark continent', and 'the world's burden' (The Economist 2000). Africans have strongly resisted such narrative that tends to dismiss historical realities of Africa's rape through slavery, colonialism, economic dependency and continued dominance by the international institutions of global governance (World Bank, IMF and WTO) and external involvement and influence of the great powers on the continent.

I Research and Studies Department, Division of African Politics and Integration, Nigerian Institute of International Affairs, Lagos, Nigeria. E-mail: sharksnaw@yahoo.com.

2 Research and Studies Department, Division of African Politics and Integration, Nigerian Institute of International Affairs, Lagos, Nigeria. E-mail: oluwatooni.a@googlemail.com. 
Thus, interpretations of Africa's place and role in world affairs lie between those who have completely lost hope in the continent- Afropessimists and those who hope for a better future for Africa-Afro-optimists (Clark 2013). Both viewpoints must take into account historical realities of Africa's emergence, existence and elements of continuity and change in the relations between African states and with the rest of the world. Owing to the lack of faith in Africa by the old powers, the emergence of the new economic powers, such as China, India, and Brazil, who sought to engage Africa on terms of 'partnership', 'mutually benefits', 'common history' and 'win-win' relationship, were embraced with a sense of optimism. Engagement between Africa and the new emerging economic powers have been variously interpreted, with some defining same as a 'new scramble for Africa'- suggesting that it is not different from the old scramble by European powers.

Over the past few years, the narrative has shifted to 'Africa Rising', signifying that Africa is no longer a hopeless continent, but a vast continent endowed with rich human and natural resources and whose prospects are not only rising, but increasingly being recognized by the world. Even so, it must be stated from the onset that studies on Africa in world affairs have tended to focus upon the foreign policies that African states have employed in their dealings with the outside world. While recognizing the centrality of this approach in examining Africa in world affairs, it must be underscored that the wider international system has to a very large extent 'shaped Africaparticularly the forms of state power on the continent' (Taylor and Williams 2004). At the same time, Africa's place in world affairs is being shaped by non state actors, especially international finance institutions (IFI), development and humanitarian NGOs, and transnational corporations. In addition to the forces of globalization, Africa's place in world affairs is further being shaped by international organizations. In particular, these include international organizations which African states established such as the Organisation of Africa Unity (OAU) /African Union (AU), African Development Bank, and regional organizations as building blocks for regional integration and development.

Our task in this article is to examine and to discuss how African affairs contribute in shaping the world and how Africa in turn is being shaped by international processes and structures. Accordingly, the article will attempt an examination of Africa in world affairs from slavery to colonialism; sovereignty, African states and world politics; Africa and the global political economy; Africa and international organizations, particularly the UN; Africa relations with the traditional and emerging economic powers, and the future of Africa in world politics. 


\section{Africa in World Affairs - From Slavery to Colonialism}

It has been argued that Africa did not evolve in isolation prior to European colonisation. The continent, like some parts of the world, had to adapt to invasions and imperial rule. Africa was also subject to religious influences, namely Islam and Christianity. Africans participated in the international economy prior to colonialism. By the fifteenth century, the continent had built strong land and maritime trading links with Arabs, Asians and Europeans. Trading activities with European merchants opened the gateway for the entry of the European colonial powers who desired control of activities in the continent of Africa. The Portuguese, Dutch, French and British established trading post in various parts of Africa. By the eighteenth and nineteenth centuries, numerous trading posts could be found along Africa's coastline, with Europeans engaged in buying gold, ivory and later the transatlantic slave trade. The transatlantic slave trade took place across the Atlantic Ocean from the I5th to the Igth centuries. The Atlantic slave trade was significant in transforming Africans from a small percentage of the global population of slaves in 1600 into the overwhelming majority by I800. The Portuguese who were among the early arrivals in Africa turned to enslaved Africans to cultivate the sugar and other crops on their plantations. Slavery to a very large extend affected negatively the demography and economy of Africa and for the European economy, it 'signaled the rosy dawn of the era of capitalist production' (Marx I867). Even after its abolition, the effects of the Trans Atlantic slave trade in Africa cannot be wished away as it constituted the destruction of culture, language, religion and sustained a legacy of racism. This situation was to change dramatically, however, in the second half of the nineteenth century.

The scramble for Africa brought into sharper focus imperial competition for access to control of African lands (Thompson 2010). For economic, strategic and cultural reasons, agreements were ratified at the I884-85 Berlin Conference hosted by Germany's Chancellor, Otto von Bismarck, and this meeting saw Africa carved up between the European powers (Adekaye 20I0). Only the empire of Ethiopia and the territory of Liberia escaped this partition. France was to take possession of North, West and Central Africa; Britain claimed West, East, Central and Southern Africa; Portugal laid claim to the territories of Angola, Mozambique and Guinea-Bissau; King Léopold of Belgium was awarded the Congo; Italy sought to control in Libya, Eritrea and part of Somalia; Spain did likewise in north Morocco, the Spanish Sahara and Spanish Guinea; while Germany gained areas in the south-west and the east of the continent, as well as the Cameroons and Togoland. Germany, however, was to lose these possessions 
as a consequence of its defeat in the First World War.

The impact of colonialism on the subsequent political, economic and socio-cultural environment was extensive. Elements within this colonial inheritance of particular importance are: the incorporation of Africa into the international political economy as a weak participant, the imposition of arbitrary boundaries; the reinforcement of the non-hegemonic state; the weak link between state and civil society; the promotion of an African state elite ill schooled for developmental pursuit; the building of specialist export economies; and the absence of strong political governance institutions.

\section{Sovereignty, African States and World Politics}

Pan-Africanists such as the late Kwame Nkrumah, Julius Nyerere, Nnamdi Azikiwe, Obafemi Awolowo, Jomo Kenyatta and many others provided leadership in the nationalist movements in their respective countries in the struggle that eventually forced the European powers to grant independence to African countries. Even after independence, African states and the artificial boundaries created remained direct products of the European colonization. Decolonisation, therefore marked a revolutionary change in the basis of statehood in Africa. African leaders acquired rights of sovereignty regardless of the political or socio-economic conditions or prospects of the colonies they inherited. As newly independent states, they sought to defend their sovereign status in world politics. The international system, and particularly the United Nations (UN), collaborated to establish and preserve a large number of new independent states from Africa. Changes occurred in the years following World War II, during which colonialism became an aberration. Beginning in the late I940s, with the independence of the Philippines, India, Pakistan, Indonesia, Sri Lanka, and a few other Asian states, a world-wide movement for the independence of all colonies gathered momentum. .

Once colonialism lost its legitimacy, the movement for independence could not stop until all colonies became self-governing. The international community centred in the UN came to replace colonialism as the moral, legal, and material aid structure that maintained Africa. The Organisation of African Unity (OAU), which was formed in I963 primarily to promote unity and preserve the territorial jurisdictions inherited from the colonial era, reinforced the external supporting structure of international legitimacy by forbidding the use of force and subversion to undermine the independence of member states. After independence, the artificial and poorly demarcated borders of many countries were considered the most potent source of conflict and political instability (Ikome 20I2). This resulted in heated 
debates on whether to revise or maintain the colonial borders. However, the OAU/AU elected for maintain the status of sanctity of colonially created borders to avert the likelihood of chaos and anarchy resulting from boundary contestations. In spite of this decision, border conflicts became a source of instability and conflict.

Significantly, although intra-state conflicts seem to have replaced inter-state conflicts as the principal source of instability on the continent since the late I980s, the prospect of destabilising border conflicts is still very real, particularly against the background of Africa's ever-expanding population, which is accompanied by shrinking economic resources and opportunities, and high levels of migration and climate change. There have been recurring invasions, occupations, problems with refugees, border incidents, and other international clashes since independence. Examples are: Tanzania's invasion of Uganda to overthrow the regime of Idi Amin during I978-9; Morocco's forcible occupation of large areas of Western Sahara since 1976; a prolonged war between Somalia and Ethiopia over a disputed region; invasions of southern Zaire in 1977 and again in 1978 by separatists in an apparent attempt to seize political control of the copper-rich Shaba Province, the Nigerian Civil war of I967-I970, and contestations between the Sudan and South Sudan, are some examples. Some governments have serious difficulty exercising control over their territorial jurisdictions in the face of external and internal adversaries. These include Angola, Chad, Somalia, Sierra Leone, Liberia, Nigeria, and other countries with rebels or local warlords, and insurgents

\section{Africa in International Organizations: The UN as the World's Most Universal Organization}

International organisations, irrespective of their objectives, locations, size of membership and geographical spread, are created first and foremost, as a result of what can be described as broad complementarity of interests among the members. International organisations which African states belong to at least one or the other like OAU/AU, UN, and Commonwealth are essentially designed to complement the efforts of states in promoting and consolidating their perceived national interests. In the absence of a 'world government' to regulate the behaviour of states as they engage in the struggle for power, states use diplomacy as a key instrument for ensuring order in the international system that would enable them promote their national interests. Thus, international organizations provide African states with the opportunity to conduct multilateral diplomacy and in turn promote inter-state cooperation, shared values and interests. 
The UN, created in I945, embodies ideals of justice and inequality on the one hand. On the other hand, the power politics embodied in its structures, particularly the powerful five members Security Council, often mean that the Great Powers can manipulate the system to their advantage. The discussion on Africa and the UN is thus an analysis of how Africa has sought to transform itself on the platform of the UN and negotiate its way against the background of great power politics and Africa's search for recognition as an influential player in world politics. According to McKay (I963, I) the rise of Africa was dramatized to the entire world by the turmoil at the 15 th Session of the United Nations General Assembly. That signaled the first appearance of a number of African leaders who were welcomed by world leaders and who later took up the issues of decolonisaiton and anti-apartheid struggle to the front burner of the UN debates. Africa played an important role along with supportive countries from Asia, Latin America and the Soviet bloc, in the Group of 77 (G77) and China, on issues of decolonization, sanctioning apartheid, and promoting socioeconomic development.

African states engaged in a struggle against colonialism, apartheid, and racial rule under the platform of the OAU, UN and other platforms until the vestiges of these evils were crushed following the granting of independence to South Africa and the enthronement of democracy in the country. Even so, the issue of Western Sahara under Morocco remains a vexed issue necessary in closing the chapter on decolonization in the continent. Presently, Africa provides the UN with 55 out of its I94 members. That is not to say that African countries are always united. One of the most thorny issues in the relations between Africa in the UN in recent times has been the failed reform of the UN Security Council, from 2004-2005. The failure to reform the UN in 2005 has several implications. A reconstituted UNSC would almost certainly give Africa an enhanced presence at the top of the table of global diplomacy, helping to ensure that with consistent strong representation, the continent could seek to check the excesses of the great powers $\left(\mathrm{P}_{5}\right)$ and ensure that Africa's security concerns are taken more seriously. This is particularly important given that about 60 percent of the Council's deliberations focus on the continent and that in 2009 about 70 percent of UN Peacekeepers were deployed to Africa.

\section{Africa and the Global Political Economy}

Africa's position and role in the global economy has to be understood in a context. Since the Igth century, Africa's political economy has left it marginalized and highly dependent on outside actors and forces. It has 
been established that Africa is well endowed in terms of raw materials and natural resources, yet Africa still occupies a weak place in the global economy. From the I6th to early Igth centuries, Africa played an important part in the growth and development of the world economy, albeit only as a source of slave labor for the white settler plantations and mines in the New World. During the Igth century, the continent was progressively transformed as an additional source of industrial raw materials for European factories and also as market for goods from the factories. By the mid ig8os to the late I990s, the marginalization of Africa had increased. The decline of Africa was two-fold. The first, primarily economic, aspect was that Africa was no longer regarded as important to the major actors in the world economy. As such Africa was not attractive to investors, multinational corporations and international banks.

The second aspect of Africa's marginalization was that with the end of the Cold War, African countries became less of political and strategic importance for the world major powers. Africa generated a declining share of world trade, and the main commodities it produced were becoming less important or were being produced by other developing countries. Africa's per capita income levels and growth rates declined after the first oil crisis in I973, while its percentage of worldwide official development assistance rose from I7 percent to about 38 percent in I99I (Callaghy 2016, 40). Africa's marginalization became more obvious when Africa's performance in the areas of agricultural production, level and quantity of investment was compared with that of other low-income countries. This was particularly true in regard to South Asia, which had performed better than Africa within the same period. Given the ensuing scenario, by I980-I990s, Africa became more dependent on intrusive external actors. In the I980s, Africa became more linked to the world economy as an extreme dependence on external actors, particularly the International Monetary Fund (IMF) and the World Bank. These public financial institutions played key roles in determining and influencing Africa's economic policy. In I974, total African debt was about US\$I4.8 billion, by I992, it had risen to US\$I50 billion amounting to more than Ioo percent of the total GNP (Callaghy 2009, 5I). By I996, the IMF and the World Bank had designated forty one African countries as 'Heavily Indebted Poor Countries' (HIPC). Much of Africa's debt was owed to international financial institutions (IFI), especially the World Bank and IMF, and resulted largely from the borrowing associated with stringent conditionalities.

The difficult external debt burden and the resulting desperate need for foreign exchange made African states very dependent on a variety of external actors, all of whom used their leverage to encourage further economic 
liberalization and to convert same into economic policy conditionality. The bottom line is that after more than two decades of implementing the western driven SAP, African economies were worst off. Not only did Africa critique and sought for alternatives to SAP (AAF-SAP I989), it questioned the entire western model of development or so called Washington Consensus. Part of the modification of SAP based on poor record was the introduction of the notion of good governance and democracy. Due to dramatic political changes in the world in I989-1990, and the search for new foreign policy thrust to replace containment, the USA transformed governance into a political conditionality focusing on democracy and civil society. The new conditionality which intertwined with the economic conditionality created a dilemma for African countries that were required to reform and adopt democratic systems of government.

By the end of the I990s and early 2000s, it became clear that if Africa was to address the problems of poverty, diseases including HIV/ AIDs, collapse infrastructure, educational backwardness and other negative indices, and to achieve the Millennium Development Goals (MDGs) - now Sustainable Development Goals (SDGs), there had to be a dramatic change in the strategic relationship between Africa and the powerful external actors. This entailed a serious campaign for debt relief, supported by advocacy groups and international NGOs and which partly account for the creation of the Multilateral Debt Relief Initiative (MDRI) by the USA. By mid-2007, the debt stock of about 30 African countries that had completed the combined HIPC and MDRI process had been reduced by 85 percent.

Nigeria was one of the countries that benefited from the debt relief campaign. Nigeria's external and internal debts which stood at about US \$25 billion in 1999 when the government of Obasanjo government assumed office rose to US\$34 billion as at the end of 2004. Debt had constituted a heavy burden on Nigeria and stood as major obstacle to sustainable development. Nigeria was spending about US\$I billion annually to service the debt, leaving the country with less than US\$2 billion to meet her developmental commitments, especially in the area of provision of amenities and infrastructure for human development and socio-economic growth (Ogwu and Alli 2006: II). The biggest achievement of Obasanjo debt relief diplomacy was the October 2005 debt deal which led to exit of Nigeria from the Paris Club. This debt relief offered to Nigeria amounted to an US\$I8 billion debt write off, to pay off the balance of approximately US\$I2.4 billion to the creditors over a period of six months. When we compare where Africa stood at independence and more than half a century after independence, we can argue that lots of changes have taken place in the continent.

The continent is no longer described as the Dark Continent, a lost 
cause or a continent without hope. The World Bank described 2005, and declared by the British as the Head of the G8 to be the 'Year of Africa', as part of the move towards a Decade of Africa. This was in acknowledgement of improvements in Africa's standing in world politics. Compared to the I980s, growth rate of I.8 percent, with a per capita growth of -I.I, the I990S brought 2.4 percent and 0.2 respectively. By contrast, 2000-2004 brought growth rates of 4.8 and I.6 percent. Exports also grew from 0.0 percent, 5.0 percent and 3.7 percent for the three periods respectively. The growth rate for 2005 was 5.3 percent, marking a sharp departure from the weak and volatile growth of the I980s and I990s. Foreign direct investment (FDI) flows also improved after I999 (Callaghy 2009, 59). Two thirds of the net 2006 increase of US\$2 billion in foreign direct investment was concentrated in five countries- Nigeria, Sudan, Angola, Equatorial Guinea, and South Africa. The attraction of cause is oil, gas and mineral resources. To a very large extent, the extra flow of investment stem from the increased presence of emerging economic powers such as China and India in Africa. From a hopeless case, the discourse on Africa in the global economy has since shifted to that of African rising.

\section{Great Powers Interest in African Affairs and Africa's Relations with Emerging Powers}

The major powers in Africa before World War I including the British, the French, the Portuguese, Belgians, Germans, and Italians were attracted to the continent's endowments including vast raw materials, natural resources and land for territorial expansion. The scramble for Africa, colonialism and imperialism, which became features of narratives of Africa in world politics were largely products of vested interests of the great powers. Broadly speaking three major reasons account for the interest of the great powers in Africa and these can be categorized as political/ strategic, cultural, and economic. While the economic motivation has been stated above, the political motivations began with the political rivalry among European states for dominance in the international system of the eighteenth century. The great powers believed that colonial possessions conferred prestige and status. Even today, one can argue that possessions and wealth still bestow a great deal of status on those who have them. Large countries still compete for influence among small states. The competition between the United States and the former Soviet Union in the Cold War era rested in part on the drive for leadership and dominance in world affairs. Beyond the psychological satisfaction of being a great power, acquisition of a colony also provided a large reservoir of manpower to be drawn upon in 
time of war. According to President Woodrow Wilson, 'During World War I, the war, to make the world safe for democracy'- nearly I million soldiers of African descent fought on the side of the Allied powers. In World War II, about 2 million Africans - and I million African Americans - served, again, on the side of those who were fighting against tyranny and oppression.

The great powers including USA, Britain, France, Russia, and Germany have continued to articulate their role in Africa in terms of their strategic interests which includes desire for access to resources, markets, and routes for navigation, and military strategic calculations. International organizations including the UN and its agencies, as well as international financial institutions and governance institution have served to promote the interests of these great powers who have continued to exert influence on African states. Given the dynamics of world politics and against the backdrop of globalization, the world has witnessed the rise of new economic powers that have sought to engage Africa for strategic reasons. With the entry of these powers, Africa has become a ground for competition between the great powers and the emerging powers from the south, particularly with China and India. The increase competition for access to Africa's resources and markets has been described as the new scramble for Africa.

China and India's increased involvement in Africa in recent years is one of the most significant developments in the region. It appears to contradict the idea of Africa's marginalization in world affairs and brings significant economic and political consequences. The period since the end of the cold war, when observers would point to the US, France and the UK as the only foreign powers to have substantial interest in Africa has changed. China and India as well as other emerging economic powers, have established themselves as increasingly influential players across the continent. China and India are often described as the next engines of world economic growth.

The amplified presence of the two countries on the African continent is now widely noticed. Although India's presence received less attention compared to China's, it is nonetheless of substantial and increasing importance. While some have referred to re-entry of the emerging powers as a new scramble for Africa, they fail to underscore what the implications might be for Africa and for the international political economy. It is important to state that the attraction for China and India in Africa is trade and investment, interest in strategic resources such as oil and gas, solid minerals (Obi 20IO). The two emerging powers have turned to engage with Africa, and the volume of trade between the two countries and Africa has witnessed a considerable increase over the last decade, with the value of trade between China and Africa increasing by an average 24 per 
cent between 1995 and 2007 . Total trade now stands at approximately US\$ 74 billion in 2007 (Naidu 2010). Bilateral trade between India and Africa rose from US\$967 million to US\$9.I4 billion between I99I and 2005 and over the period 1997-20I7, exports from Africa to India doubled. Indian and Chinese activities on the continent have three primary channels; trade, aid and FDI. These are interrelated- trade is closely linked to the integration of African, Chinese and Indian investments into global value chains, and often Chinese and Indian aid offers are underpinned by market-seeking purposes.

Several aspects in the architecture of the global political economy have acted as midwives for China and India's engagement with Africa. Most importantly, the economic transformations in both China and India have raised strong demand for energy resources and to find new markets for their products. Improvement of transport and financial systems, and supply chains as well as in information and communication technology (ICT) are other important vectors allowing for the scale of current engagement and for an increase in FDI from both countries with India investing around US\$r.8 billion by 2004 and China US\$I.3 billion by 2005 (Naidu 20IO). Perhaps a significant factor for the increasing footprint of Indian and Chinese investments in Africa is that most states had adopted Structural Adjustment Programmes (SAPs) under World Bank and IMF austerity measures, which have created the correct market conditions for their entry and market traction. It is also worth mentioning that both recognize that Africa is undergoing increased political stability and widespread growth, an ideal trend for motivating their expansion.

To strengthen and deepen their relations with Africa, the emerging powers have used diplomatic platforms at bilateral, regional and global levels. The Forum for China-Africa Cooperation (FOCAC) meetings held in Beijing from 10-12 October 2000; Addis Ababa from 15-16 December 2003; Beijing from 3-5 November 2006; Sharm el-Sheikh, Egypt from 8-9 November 2009; Beijing from 19-20 July 2012; Johannesburg, South Africa from 4-5 December 2015, were China's strategies towards engaging Africa. Others strategies include at include bilateral and regional platforms. The 20I5 FOCAC elevated ChinaAfrica relations from a 'strategic partnership' to a 'comprehensive strategic and cooperative partnership'. At the summit, the Chinese President Xi Jinping went beyond its tradition of doubling its financial commitment to Africa at each FOCAC meeting. This time around it was tripled with a pledge of investment totaling US\$60 billion. The difference between the commitment this time around is that it was broadly defined as 'investment', including US \$5 billion for grants and zero-interest loans, US\$35 billion for concessional loans and buyer's credit, and the rest as commercial financing. 
The diversified portfolio sends several messages that China is more than confident in the economic future of Africa; that China is becoming more aggressive in its financial input in Africa; and that the assets owned by China on the ground in Africa are likely to grow. At the Johannesburg FOCAC meeting, President Xi of China proposed to overarching plans for Sino-African cooperation, covering almost all aspects of their economic ties. These include: industry, agriculture, infrastructure, environment, trade facilitation, poverty alleviation, and public health. The plan fits into the readjusted China-Africa policy since the inauguration of President Xi. Notably, industrial capacity cooperation and strategic complementarity have become two key words for China's economic aspiration in Africa. There is no doubt that China is keen on shifting its labour intensive industries to Africa. Accordingly, such industrial capacity cooperation is to be complemented by the exports of China's excess capacity to support African infrastructure projects and capacity building through technical assistance, vocational training and fellowship programs. This of course is no free lunch, neither does it rule out the possibility of inflow of more Chinese population into the African continent. FOCAC represents an important platform for China in its interactions with African leaders.

Indian has also used the diplomatic platform in an effort to deepen its relations with Africa. In recent years India has strengthened its involvement in the African Indian Ocean Rim considerably (Ganapathi 20I4). This shift in policy comes in part is because of India's desire to compete with China's growing influence in Africa. In 2004, India launched the Techno-Economic Approach for Africa-India Movement (Team-9) with eight energy- and resource-rich collaborative partners, including Senegal, Mali, Cote d'Ivoire and Ghana to whom it extended lines of credit totaling US\$500 million (Singh 2007). This engagement is indeed strategically aligned to India's resource security and to develop closer ties with energy rich countries in West Africa where its presence has been negligible (Biswas 20I6). Its biggest trading partner in the region is the Ivory Coast. In a similar fashion, the first India-Africa Summit held in New Delhi in April 2008, the second India-Africa Forum held in Addis Ababa in 20II, and the third India-Africa Forum Summit held in New Delhi, where "a model of friendship of equals" was presented, sought to be markedly different than "the Chinese template of "money for minerals" (Singh 2007, 6). Then Indian Prime Minister Manmohan Singh stated at the conclusion of the 2008 meeting that "India is not aiming to compete with China vis-à-vis its influence on Africa", and that "India is not in any race with China". In 20I3, I6 percent of India's total foreign direct investment stocks were in Africa, while Brazil and China had 9 percent and 0.8 percent of their FDI stocks in 
continent, respectively (UNECA and CII 20I5). In the current conditions of the global political economy, interdependence has emerged as a central phenomenon that brings about a diffusion of power in international relations. In this view, the global political economy might create a more suitable environment for multilateralism, the emergence of international institutions and cooperation by means of a socialization process of states through evolving norms, rules and communication.

Relating this to China and India's engagement with Africa, and given the recent nature and pace of this wave of engagement, both countries are just now starting to define what these norms, rules and forms of communication are. The unprecedented rise of China and India as emerging market forces presents a large set of simultaneously delicate, complex and comprehensive, challenges and opportunities, for the African continent. An effective divide in the developing world becomes obvious when the characteristics of these two massive economies are viewed in relation to some African countries. China and India first and foremost advance their particular interests and play the game of constituency-economics at the international negotiation table. This means that because some African economies are particularly sensitive to tremendous competition from these giants they will now tend to try and find a more concerted bargaining position in trade negotiations vis-à-vis the developed world. The shift in the global political architecture of power, in great part pushed by India and China, has allowed for this situation and provided developing countries with greater autonomy when designing their particular economic policies. Simultaneously it has brought about challenges demanding greater agency from African economic stakeholders and concerted clarity in the strategies that will design Africa's response.

\section{Africa and the Challenges of Globalization}

Africa is facing a lot of challenges on account of the phenomenon of globalization. The concept and process of globalization is multi-faced and subject to various perceptions. Essentially, the concept has come to refer to a gamut of interlocking variables. Whereas the dominant perception of globalization in Western Europe and North America is the existence of vast opportunities for world economic development and significant contributions to improving people's condition of existence, in the Third World, especially African countries, the perception of globalization is that of a dangerous process that increases inequality within and among states; a process which increases poverty and sustains disempowerment of the weak. Mazrui (200I) sees globalization as both historical and sociocultural process. As a historical and socio-cultural concept, globalization 
is thus perceived as the movement of people, language, ideas, culture and products around the world. That the concept of globalization poses a lot of challenges to Africa is not in doubt. Mazrui also noted that globalization can be seen as an advanced capitalist mode of production. His argument is that globalization represents the new material and ideological mechanisms by which the capitalist classes control the economies and societies of the world. If globalization relates to global technological determinism, then it means that Africa is operating at an unequal ground with the developed economies of the world.

The major challenge of globalization to Africa is economic. It is common knowledge that today the thematic and dialectics of capitalism has not changed at all. In this sense, globalization basically means increasing vertical and horizontal integration of world economic and social formations into the world capitalist economy. This drive towards increasing global economic integration is driven by the dominant economic powers of the west for their ultimate benefit. It is in this wise that we can understand the argument that globalization strengthens the strong and weakens the weak. In this globalized economic order, Africa is seriously disadvantaged. The economies of the continent are individually and collectively weak in comparison with economies of the USA, European Union or even the emerging economies of Asia. This economic domination by the supereconomic powers is sustained by proclaiming and promoting free trade enterprise which works to the benefit of the strongest economies to the detriment of Third World economies especially Africa. This is the neoliberal economic order which has driven the process of globalization from the earliest times and which is being promoted by international multi-lateral institutions such as the World Bank, WTO and the IMF (Asogwa 20II).

Africa is seriously marginalized and disadvantaged in a globalized world. A related challenge to the foregoing is that of technology and information dissemination. Technology drives globalization. The African economy is grossly import-substituted and it is a consumer economy that produces primary products and consumes finished products from Europe, America and Asia. Africa is technologically very dependent on forces outside the continent. This dependence is not for lack of skill, personnel or resources to develop Africa's inmate abilities but primarily due to prevailing socio-political situations that are not enabling. The implication of this is that African energy, intelligence and creativity have been employed in the development of societies other than Africa. Because of the advancement in information, and communication technology, Africa has been subjected to consuming foreign information and culture at the expense of her own. In reality, the effect of globalization on Africa is enormous. 


\section{Future of Africa in World Affairs}

There continues to be a growing interest in Africa's development challenges and the continent's future prospects. The Economist magazine which in 2000 wrote-off the continent as a 'hopeless' case, in 20 II published an edition of an African Rising- The hopeful continent (The Economist December 3, 20II). The narrative of Africa in world politics, today, is not just of the commodity boom that took place from I997 to 2007 , which accounts for much of this positive commentary, but also of Africa's engagement of new emerging partners. Africa's international relations have expanded beyond engagement with the great powers such as USA, Britain, France, to include emerging powers such as China and India that have also helped to spur Africa's economic growth. The discourse over Africa's rising is also spurred by the vast amount of vital resources found within the continent. Such critical resources are seen by the emerging powers as strategic necessities to power their own industrial growth and modernization. Beyond natural resources, the involvement of these new economic powers in Africa spans diverse sectors, such as infrastructure, ICT, agriculture, and finance, with state-driven capital fueling acquisitions in the case of China, and intensifying private sector engagement in the case of India.

In the last decade or so, Africa has turned a corner, both politically and economically. Conflicts have subsided in some countries, such as Mozambique, Angola, and Rwanda and opened up in others. There is a renewed wave of democracy, with 30 countries thus far putting in place democratic processes in the period between mid-I990 to 2008 whereas in the I980s, there were not more than four democratically elected governments. Coups are not as frequent as in the post-independence period because as the AU strongly condemns unconstitutional changes of government. Overall, Africa's future looks better than the past (Perry 20I2). On the economic front for example, Africa's collective GDP in 2008 is said to have been roughly equal to Brazil's or Russia's at US\$1.6 trillion, nearly doubling the figures of a decade early. With a combined consumer spending of around US\$860 billion during the same period, and projected to rise to US\$2.6 trillion by 2020 , there is no doubt that Africa is on an upward trajectory. The fast rate of urbanization, although likely to generate more infrastructure-related challenges and increase the burden on inadequate health facilities, water supplies, and road infrastructure, is a sign of future dynamism on the continent, especially if the growth rates keep up and more investment flows into the continent. Despite these improvements in Africa's economic structures, the fundamental conditions that assure long- 
term growth, including a proper infrastructure of governance and wellfunctioning legal, bureaucratic, and market institutions, are still lacking or are weak in a number of countries. Newer challenges have also emerged such as terrorism, the proliferation of small arms and light weapons, drug trafficking, kidnappings and a host of other challenges.

Just few years back, the outbreak of Ebola Virus Disease, in some parts of Africa, particularly Liberia, Sierra Leone and Nigeria, revealed the weak health systems in those countries. There are still a number of other constraints to Africa's development: corruption, issues related to weak governance, limited space for civil society, a weak business climate, infrastructural bottlenecks, dependence on a narrow range of products, reliance on traditional markets, underdeveloped human capital, and weak social infrastructure. No doubt, Africa's resource wealth can be a boon for the continent. Political and economic relations involving resources and development continue to develop between many African countries and emerging powers, such as Brazil, India, Russia, Turkey, and South Korea. However, the African leadership needs to manage these partnerships responsibly and with the objective of developing Africa's people. If Africa were to realize its bargaining capacity, it could better leverage relations with the old powers and emerging powers, such as China and India, to achieve much more for its growth and development.

With respect to Africa's role in the $\mathrm{UN}$, it is evident that the number of African countries in the UN has not only expanded its size, but issues that help to make the world more united. In the past six decades, through the platform of the UN, Africa waged war against colonialism, underdevelopment, human rights abuses, and insecurity and helped in the words of Nkrumah, to bring the 'African personality in world affairs'. In essence it helped to humanize the world body, transforming world politics from purely power politics of the great powers to one that has been forced to address and promote the socioeconomic needs of the world's poor. There is no doubt that addressing the issue of poverty is at the heart of the sustainable development goals (SDGs). Even so, African countries must take into cognizance the fact that there would neither be a world of moral opinion nor the means of expressing under the UN does not exist. The UN is a battle ground of ideas, a platform for promoting political, social and economic interests of nations of the world where the strong continue to have their way and the weak nations also have their say.

\section{Concluding Remarks}

In this article, we discussed Africa in world politics and argued that 
Africa has never existed apart from world politics, but has been inevitably entangled in the dynamics and flow of events and changing configurations of global power. The article also noted that the issue of Africa's position and role in world politics has been a subject of various interpretations between Afro-pessimists and Afro-optimists. Notwithstanding the diverse interpretations of Africa in world politics, the reality remains that African affairs contribute in shaping the world and Africa in turn is being shaped by global developments. Africa holds a strategic place in the world (Clark 20I3). It contains huge natural resources, including oil and gas, solid minerals and rich arable land for agricultural production and markets that attracted the great powers that partitioned, colonized and shaped the history of the continent. New economic powers are equally attracted to the vast resource and markets of the continent. Just as the world shape African affairs, its affairs also affect the world. Africa is also an important factor in world politics. It is also strategic in the world - Africa sits squarely in the middle of three of the world's most important trade routes: the Atlantic and Indian oceans and the Mediterranean Sea. Its 55 states represent over one-fourth of all votes within the UN system. Still, most African countries exert little influence in world affairs because of their weak political and economic systems and limited military capabilities. In the search for PanAfrica solutions to problems of leadership and governance, development challenges, poverty, conflicts, terrorism and many others, Africa must act in unity and sought to engage the international community on its own terms as an equal player in world politics. The relationship between Africa and the international community must equally undergo a transformative change. Relations between Africa and the world must be rooted in the principles of equality of nations and peoples; mutual collaboration for mutual interest and respect for the ability and right of Africans to lead their own change.

\section{REFERENCES}

Adebajo, Adekeye. 2oro. The Curse of Berlin, Africa after the Cold War. Scottsville: University of Kwa-Zulu Natal Press.

Asogwa, Felix Chinwe. 20II. Africa and the Challenges of Globalization: A Critical Appraisal of the Relevance of Pan-Africanism. http://www. nai.uu.se/ecas-4/panels/2I-40/panel-30/Asogwa-Felix-Chinwe-Full-paper.pdf.

Biswas, Aparajita. 20i6. "India's Energy Security Issues and Africa Oil”. In India and Africa: Common Security Challenges for the Next Decade, edited by Ruchita Beri, Io6-I2I. New Delhi: Institute of Defense 
Studies and Analysis and Pentagon Press.

Callaghy, Thomas M. 20I6. "Africa and the World Economy: Still Caught Between a Rock and a Hard Place?" In Africa in World Politics: Reforming Political Order, edited by John W. Harbeson and Donald Rothchild, 39-7I (Sixth Edition). Boulder: Westview Press.

Clark, Duncan. 2013. Africa's Future: Darkness to Destiny- How the Past is Shaping Africa's Economic Evolution. London: Profile Books.

Ganapathi, M. 20I4. "India-Africa Partnership". In India and Africa: Enhancing Mutual Engagement, edited by Ruchita Beri. New Delhi: Institute for Defense and Analyses.

Ikome, F. Nguendi. 2012. Africa's International Borders as Potential Sources of Conflict and Future Threats to Peace and Security, (Paper No.233). Pretoria: Institute of Security Studies.

Marx, Karl. 1867. "Chapter Thirty-One: Genesis of the Industrial Capitalist”. Das Kapital: Volume I,

Mazrui, Ali. 200I. Pan-Africanism and the Origins of Globalization. Lecture Delivered at Dubois Centre, Ghana.

McKay, Vernon. 1963. Africa in World Politics. New York: Harper and Row.

Naidu, Sanusha. 20I0. "India's African Relationship in the Shadow of China?" In The Rise of China and India in Africa, edited by Cheru Fantu \& Obi Cyril, 34-49. Uppsala: The Nordic Africa Institute.

Obi, Cyril. 20I0. "African Oil in the Security Calculations of China and India". In The Rise of China and India in Africa, edited by Cheru Fantu \& Obi Cyril, I8I-I92. Uppsala: The Nordic Africa Institute.

Ogwu, U.Joy and Alli, Warisu O. 2006. Debt Relief and Nigeria's Diplomacy, (eds.). Lagos: Nigerian Institute of International Affairs.

Perry, Alex. 20I2. "Africa Rising - It is the World's Next Economic Powerhouse, But Huge Challenges Lie Ahead". Time Magazine, December 3, 2012.

Singh, Sushant K. 2007. India and West Africa: A Burgeoning Relationship. Chatham House Briefing Paper, AFP/ASP BP 07/OI.

Taylor, Ian and Williams, Paul. 2004. "Introduction: Understanding Africa's Place in World Politics." In Africa in World Politics: External Involvement on the Continent, edited by Ian Taylor and Paul Williams, I-22. New York: Routledge,

The Economist, I3 May, 2000.

. December 3, 20II Africa Rising, The hopeful continent.

Thompson, Alex. 20I0. An Introduction to Africa Politics. London: Routledge 
UNECA. I989. The African Alternative to Structural Adjustment Programme for Socio-economic Recovery and Transformation (AAF-SAP). Addis Ababa: UNECA.

UNECA and CII. 20I5. Africa-India: Facts and Figures. Addis Ababa: United Nations Economic Commission for Africa and Confederation of Indian Industries.

Zartman, I.William. I995. Collapsed States: The Disintegration and Restoration of Legitimate Authority. Boulder: Lynne Rienner.

\section{ABSTRACT}

African affairs contribute in shaping the world and Africa in turn is being shaped by by dynamics in international processes and structures. Africa's position and role in world politics has been a subject of various interpretations between Afro-pessimists and Afro-optimists. The objective of this article is to examine, through a historical perspective, Africa in world affairs from slavery to colonialism; sovereignty, African states and world politics; Africa and the global political economy; Africa and international organizations, particularly the UN; African relations with the traditional and emerging economic powers, and the future of Africa in world politics. It made a strong case that studies on Africa affairs must take into full account historical realities of Africa's emergence in the world system, its existence and elements of continuity and change in the relations between African states and with the rest of the world. Africa's international relations have expanded beyond engagement with the great powers such as USA, Britain, France, to include emerging powers such as China and India. Accordingly, the narrative on Africa is gradually changing from a hopeless continent to an African rising. Given these developments, Africa must act in unity in addressing its many challenges, and seek to engage the international community as an equal player in world politics. The article recommends that the relationship between Africa and the international community must equally undergo a transformative change. It must be rooted in the principles of equality of nations and peoples; mutual collaboration for mutual interest and respect for the ability and right of Africans to lead their own change.

\section{KEYWORDS}

Africa; World Affairs; AU.

Received on August 4, 2017. Approved on December 20, 2017. 